\title{
Jacobus de Saraponte's Aurissa: Evidence for Multilingual Preaching
}

\section{Jan Odstrčilík*}

One of the key questions of sermon studies on medieval multilingual sermons is whether and to what extent - multilingual preaching actually occurred. The unpublished and littleknown medieval art of preaching Aurissa, composed by Jacobus de Saraponte in the 14th century, provides unique insights into this issue.

This study reconstructs the original composition of the work that was unknown until now. The article argues that the treatise consisted of three parts: the main treatise Theologia est sciencia (the only part described as Aurissa in the past), an additional chapter on preaching in the chapter and a list of rhymed words grouped thematically called the Quadrangulum.

The study then provides an overview of the main 33 chapters, focusing on the peculiar terminology of the treatise, especially so-called notabilitates and the ways in which they can be extracted from the thema of the sermon. This leads to the main part of the article, which discusses the advice on the use of various languages. Jacobus de Saraponte provides detailed instruction on which languages should be used in different parts of the sermon (thema, initial prayer, notabilitates, conclusion) with regard to different audiences. Most notably, he mentions the possibility of mixed sermons. This type is described especially in his detailed advice regarding preaching in the chapter. Finally, the study investigates traces in the manuscripts showing how they were used. The conclusion discusses the degree to which the advice by Jacobus de Saraponte can be taken as evidence for so-called macaronic preaching, i.e., the type of preaching where languages would be mixed seemingly randomly within sentences.

Keywords: multilingualism, Middle Ages, preaching, ars praedicandi, sermons

One of the most crucial questions regarding the multilingual sermons of the Middle Ages is their relation to the spoken word. Were they just a written phenomenon or did multilingual preaching actually occur?

This preliminary study introduces an unedited and little-known treatise from the 14th century that offers surprisingly clear answers to this complicated question. It is usually called Aurissa and it belongs to the medieval genre of artes praedicandi, medieval guides for preachers dealing with the right composition and delivery of sermons. This treatise is usually ascribed in manuscripts to the otherwise unknown frater Jacobus de Saraponte, whose name connects him to Saarbrücken in today's Germany in the state of Saarland. ${ }^{1}$ Besides that, nothing is known about him. His only known work, however, gained substantial popularity.

* Correspondence details: Jan Odstrčilík, Institute for Medieval Research, Austrian Academy of Sciences, Hollandstraße 11-13, 1020 Vienna, Austria; email: Jan.Odstrcilik@oeaw.ac.at.

1 Occasionally we find different attributions, like Annissa (?) fratris Nicolai in Brandenburg, Domstiftsarchiv und -bibliothek, Ki 1952, fol. 1r or Explicit discursus Alani in Darmstadt, Universitäts- und Landesbilbiothek Darmstadt, Hs. 668 , fol. 279 v. 
Aurissa has escaped modern scholarly attention almost completely until now with only scattered observations in the literature. Franco Morenzoni briefly discussed the topic of the use of various languages in Aurissa as a part of his longer study on languages used by preachers from 2008. ${ }^{2}$ Morenzoni quoted the München, BSB, Clm 16508, but was probably not aware of the real extent of the work (as will be discussed later). Aurissa was also briefly discussed in the Czech secondary literature. In 1891, Adolf Patera quoted a short excerpt of it from the manuscript kept in Wilhering, Zisterzienserkloster, Cod. IX 122, and attributed the work to an unknown Czech author. ${ }^{3}$ His mistake was corrected by Jan Vilikovský in 1940, who identified it as a work by Jacobus de Saraponte. ${ }^{4}$

\section{Manuscripts}

Existing repertories of artes praedicandi list eight ${ }^{5}$ and fourteen manuscript ${ }^{6}$ witnesses of this treatise, respectively. In manuscript catalogues I have found 34 manuscripts containing this work so far. They are preserved in libraries in Germany, Austria, the Czech Republic, Poland, Hungary and Switzerland, and the vast majority of them are dated to the 15th century ${ }^{7}$. This study is based on 33 of them:

1. Admont, Benediktinerstift, Cod. 209, fol. 115r-120r

2. Basel, Universitätsbibliothek, A II 36, fol. 203v-205r (first 8 chapters)

3. Bernkastel-Kues, Bibliothek des St. Nikolaus-Hospitals, 104, fol. 90r-105r

4. Brandenburg, Domstiftsarchiv und -bibliothek, Ki 1952, fol. 1r-19v

5. Darmstadt, Universitäts- und Landesbibliothek Darmstadt, Hs. 668, fol. 265r-279v

6. Esztergom, Esztergomi Főszékesegyházi Könyvtár, Ms. I. 213, fol. 17r-25r

7. Gdańsk, BG PAN, Ms. Mar. F 253, fol. 159r-165r (TOC on 169r)

8. Gdańsk, BG PAN, Ms. Mar. F 295, fol. 218r-218v (first 8 chapters) ${ }^{8}$

9. Gdańsk, BG PAN, Ms. 2014, 205r-211r

10. Göttweig, Benediktinerstift, Cod. 250 (red), fol. 1r-7r

11. Graz, Universitätsbibliothek, Ms. 348, fol. 87ra-94vb

12. Graz, Universitätsbibliothek, Ms. 928, fol. 161r-164r (excerpt)

13. Graz, Universitätsbibliothek, Ms. 971, fol. 1r-11r

14. Leipzig, Universitätsbibliothek Leipzig, Ms. 158, fol. 289r-295r

15. Melk, Benediktinerstift, Cod. 1580, fol. 144r-163v

16. München, BSB, Cgm 660, fol. 191ra-20ora

17. München, BSB, Clm 4784, fol. 150r-154v

18. München, BSB, Clm 12389, fol. 29r-41v

2 Morenzoni, Les prédicateurs, 505-506.

3 Patera, Mistra Jana Husi česká kázání, 355-356.

4 Vilikovský, Kazatelství, 293.

5 Caplan, Mediaeval Artes Praedicandi, No. 173, 21-22.

6 Charland, Artes praedicandi, 52.

7 Three manuscripts dated to the 14th century in their respective catalogues are exceptions: Praha, Knihovna Metropolitní kapituly, D 61; Praha, Knihovna Metropolitní kapituly, F 75 and Wrocław, Biblioteka Uniwersytecka, I F 311. Moreover, Gdańsk, Biblioteka Gdańska Polskiej Akademii Nauk, Ms. Mar. F 295, München, BSB, Clm 12389 and Praha, Národní knihovna, VIII A 19 are dated between the 14th and 15th centuries.

8 This is a different fragment than in Basel, Universitätsbibliothek, A II 36. 
19. München, BSB, Clm 16226, fol. 189r-201v

20. München, BSB, Clm 16508, fol. 214vb-223vb

21. Olomouc, Vědecká knihovna, M I 259, fol. 1v-17v

22. Praha, Knihovna Metropolitní kapituly, D 61, fol. 1r-18v

23. Praha, Knihovna Metropolitní kapituly, F 75, fol. 2r-12r

24. Praha, Národní knihovna, VIII A 19, fol. 43r-48r

25. Sankt Florian, Bibliothek des Augustiner Chorherrenstifts, XI. 96, fol. 256r-265r

26. Tübingen, Universitätsbibliothek, Mc 127, fol. 1ra-7va

27. Vyšší Brod, Cisterciácký klášter, 92, fol. 187v-204r ${ }^{9}$

28. Wien, Österreichische Nationalbibliothek, Cod. 4553, fol. 262r-273r

29. Wien, Schottenstift, 232, fol. 6r-14v

30. Wilhering, Zisterzienserkloster, Cod. IX 122, fol. 103r-118v

31. Wrocław, Biblioteka Uniwersytecka, I F 311, fol. 157v-164v

32. Wrocław, Biblioteka Uniwersytecka, I Q 152, fol. 280r-295v

33. Wrocław, Biblioteka Uniwersytecka, IV Q 73, fol. 120r-135v

Unfortunately, the last manuscript seems to have been lost during the Second World War: Warszawa, Bibliotheka Narodowa, Lat.Q.ch.I. $57^{10}$

At the moment, it is still too early to establish the stemma codicum. For this reason, the quotations for general parts of this study are mainly taken from three manuscripts that preserve the text in good quality: Esztergom, Esztergomi Főszékesegyházi Könyvtár, Ms. I. 213, Olomouc, Vědecká knihovna, M I 259 and Wrocław, Biblioteka Uniwersytecka, I F 311.

What is Aurissa?

The answer to this question is rather complex. Existing repertories understand the title Aurissa to refer only to a treatise with the incipit Theologia est sciencia pro naturato a naturante (hereinafter Theologia est sciencia). It usually consists of 33 chapters divided into two main sections. The first one is concerned mainly with defining basic terms (e.g.: what is theology, what are various meanings of the scripture, what is a sermon), and it discusses the structure of a sermon. The second section combines more various topics. Its main focus lies in the correct interpretation of the Bible and delivery of sermons. We will look at both sections in detail later.

9 In this manuscript Theologia est sciencia is divided into two parts in reversed order. The treatise starts on fol. 194r and continues until fol. 204r. The 28th chapter (Cum vis sermocinari) then starts on fol. 187v, the treatise continues until fol. 193v where it finishes with the Modus in capitulo sermocinandi; see Pavel, Beschreibung, 274. This issue, perhaps caused by incorrect binding, led the cataloguer to describe the preceding part (i.e. from the 28th chapter) as an independent work. This position was later also adopted by Josef Tř́šska, see Tř́šška, Příspěvky III, 10.

10 Kaliszuk, Codices deperditi 2/2, No. 748, 783-785. 
In some cases, Theologia est sciencia ends with obscure verses, whose nature forces me to leave them untranslated here (Olomouc, Vědecká knihovna, M I 259, fol. 14r): ${ }^{11}$

Explicit Aurissa, michi lector, sis precorissa. ${ }^{12}$

Quam nec tu nec ego nec iste, sed illius echo

Qui facit non fit, facit et fit, non facit et fit.

Non relegas versus cui presit nescio sensus

Perdicitur, persequitur, persubditur, peradditur, peradiungitur. ${ }^{13}$

There are two other texts that can be found in several manuscripts directly following Theologia est sciencia. The first one is a short text contained in nine manuscripts. ${ }^{14}$ Usually, it does not have any title. For our purposes, I will use the one that can be found in the manuscripts Praha, Knihovna Metropolitní kapituly, D 61, fol. 15v, and Esztergom, Esztergomi Főszékesegyházi Könyvtár, Ms. I. 213, fol. 49r: Modus sermonizandi in capitulo (hereinafter Modus sermonizandi). Caplan and Charland list this little text as a separate item in their repertories without connection to Theologia est sciencia, ${ }^{15}$ and it is also mentioned as such by Siegfried Wenzel. ${ }^{16}$ However, a close look at it shows otherwise: it is written in the same style as Theologia est sciencia, it uses the same terminology, and most importantly, its author speaks about Theologia est sciencia as his own work and refers to it. These features allow us to assume with certainty that this short text was an original part of Aurissa, probably a supplementary chapter or postscript. It provides additional instruction on the use of various languages in preaching that complements the rules given in Theologia est sciencia.

11 These verses are present in Admont, Benediktinerstift, Cod. 209, fol. 119v; Bernkastel-Kues, Bibliothek des St. Nikolaus-Hospitals, 104, fol. 104v-105r; Brandenburg, Domstiftsarchiv und -bibliothek, Ki 1952, fol. 19v; Budapest, Esztergom Bibliotheca, MS I 213, fol. 49r; Leipzig, Universitätsbibliothek Leipzig, Ms 158, fol. 295r; Melk, Benediktinerstift, Cod. 1580, fol. 16or; Praha, Knihovna Metropolitní kapituly, D 61, fol. 15r, Wien, Schottenstift, 232, fol. 14v and Wrocław, Biblioteka Uniwersytecka, I F 311, fol. 164v.

12 Praha, Knihovna Metropolitní kapituly, F 75 contains only a single verse that seemingly starts the same but ends differently (fol. 12r): Explicit Aurissa, per quam sint scismata scissa.

13 This particular verse is missing in Bernkastel-Kues, Bibliothek des St. Nikolaus-Hospitals, 104; Brandenburg, Domstiftsarchiv und -bibliothek, Ki 1952 and Leipzig, Universitätsbibliothek Leipzig, Ms 158.

14 Brandenburg, Domstiftsarchiv und -bibliothek, Ki 1952; Esztergom, Esztergomi Főszékesegyházi Könyvtár, Ms. I. 213; Gdańsk, Biblioteka Gdańska Polskiej Akademii Nauk, Ms. Mar. F 253; Gdańsk, Biblioteka Gdańska Polskiej Akademii Nauk, Ms. 2014; Melk, Benediktinerstift, Cod. 1580; Praha, Knihovna Metropolitní kapituly, D 61; Olomouc, Vědecká knihovna, M I 259; Vyšší Brod, Cisterciácký klášter, 92 and Wrocław, Biblioteka Uniwersytecka, I F 311. Caplan, Mediaeval Artes Praedicandi, No. 49a, 9; Charland, Artes praedicandi, 100.

16 Wenzel, Macaronic sermons, 108, n. 10. 
The second text is a long list of words without any explanation about what it means or how it should be used. It can be found in nine manuscripts, which do not always contain Modus sermonizandi. ${ }^{17}$ Praha, Knihovna Metropolitní kapituly, D 61, Wrocław, Biblioteka Uniwersytecka, I Q 152 and Wrocław, Biblioteka Uniwersytecka, IV Q 73 give this list a title, the Prague manuscript uses Et hoc quadrangulum ("And this quadrangle") and the manuscripts from Wrocław Incipit quadrangulum (»Here starts the quadrangle«) ${ }^{18}$ (hereinafter Quadrangulum).

Manuscripts Vyšší Brod, Cisterciácký klášter, 92 and Olomouc, Vědecká knihovna, M I 259 divide the list into five subsections and provide the table of contents: ${ }^{19}$

- Membra Christi

- Membra ecclesie triumphantis

- Membra ecclesie militantis

- Membra diaboli

- Membra inferni

In the manuscripts from Wrocław, the list of words is divided similarly, however, with different names and without the table of contents:

- Membra solius dei

- Membra regni celorum

- Membra huius mundi ${ }^{20}$

- Membra dyaboli

- Membra regni dyaboli

The original structure of the list is well preserved, especially in Vyšší Brod, Cisterciácký klášter, 92 and Olomouc, Vědecká knihovna, M I 259, which both show groups of four thematically grouped words (as the title Quadrangulum ["Quadrangle»] suggests) with the same consonance or rhyme. In the following examples, I will use the manuscript from Olomouc. ${ }^{21}$

17 Admont, Benediktinerstift, Cod. 209; Melk, Benediktinerstift, Cod. 1580; München, BSB, Clm 16508; Praha, Knihovna Metropolitní kapituly, D 61; Olomouc, Vědecká knihovna, M I 259; Sankt Florian, Bibliothek des Augustiner Chorherrenstifts, XI. 96; Vyšší Brod, Cisterciácký klášter, 92; Wrocław, Biblioteka Uniwersytecka, IV Q 73; Wrocław, Biblioteka Uniwersytecka, I Q 152.

18 All translations are my own, unless otherwise indicated.

19 The same subdivision can be found in part in Praha, Knihovna Metropolitní kapituly, D 61.

20 Wrocław, Biblioteka Uniwersytecka, IV Q 73 lacks this particular subtitle.

21 I am especially grateful to Rostislav Krušinský, the librarian of Vědecká knihovna v Olomouci, who provided me with the images of the manuscript. 


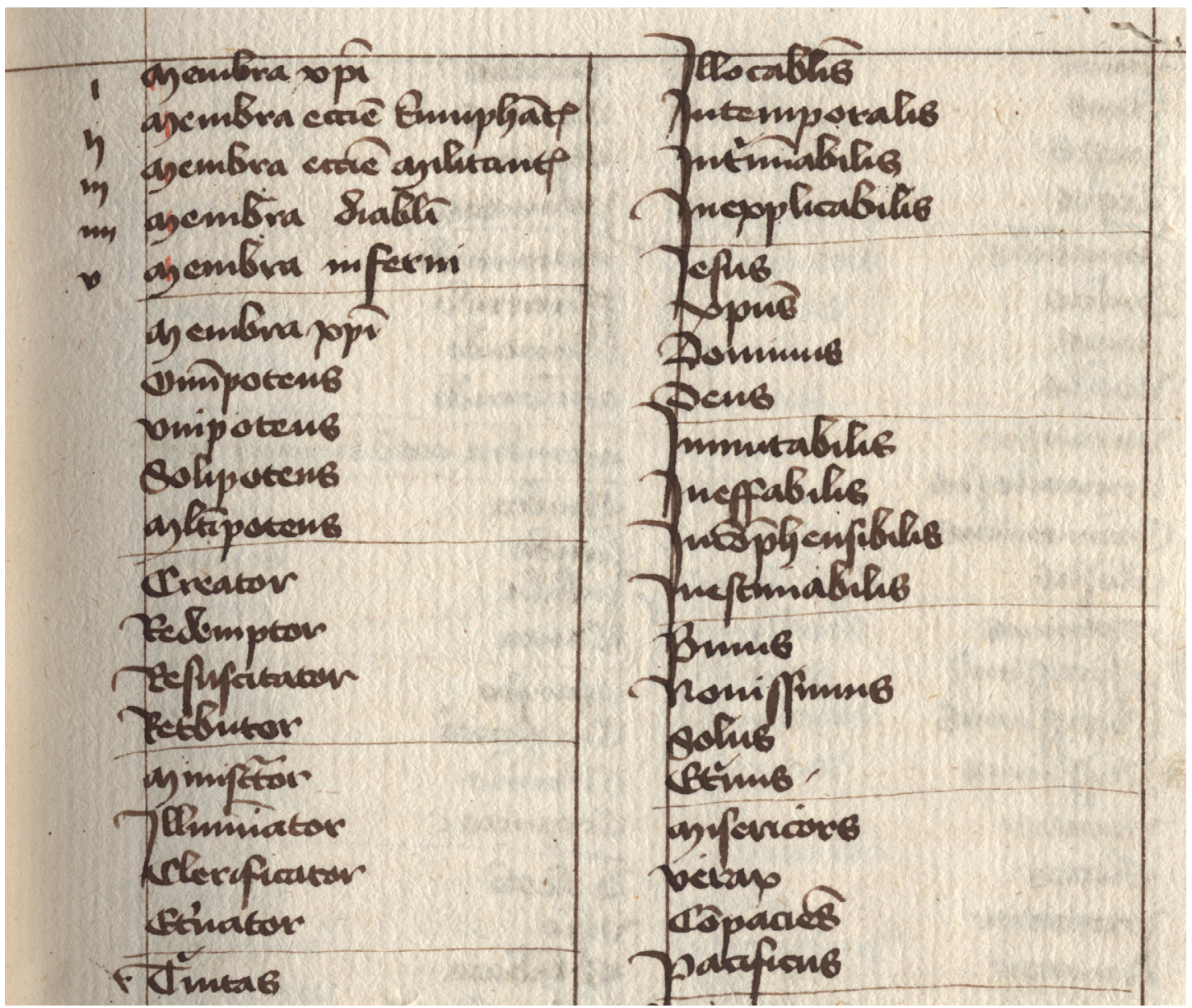

Fig. 1: Olomouc, Vèdecká knihovna, M I 259, fol. 15 r

Words in each group always belong to one of the main grammatical categories - substantives, adjectives, verbs, participles, and adverbs, e.g. (Olomouc, Vědecká knihovna, M I 259, fol. 15r):

- inmutabilis

- ineffabilis

- incomprehensibilis

- inestimabilis

The verbs are sometimes provided in the infinitive form but they also appear as imperatives or conjunctives, e.g. (Olomouc, Vědecká knihovna, M I 259, fol. 17r):

- venias

- procedas

- curras

- accipias 
For a proper understanding of these lists, we have to turn to Theologia est sciencia. Its 32nd chapter is called De quadrangulo - i.e. the same title as in the lists in the above-mentioned manuscripts Praha, Knihovna Metropolitní kapituly, D 61 and Wrocław, Biblioteka Uniwersytecka, I Q 152 and Wrocław, Biblioteka Uniwersytecka, IV Q 73. In this particular chapter Jacobus de Saraponte describes a device that will help the reader in finding suitable key term ${ }^{22}$ for the grid of the sermon - the division and its further subdivision. ${ }^{23}$ Another rule formulated in the same chapter postulates that the divisional key terms should be in consonance. ${ }^{24}$ This description corresponds to the list discussed above. Similar lists of key terms, sometimes rhymed, were used in other texts of the ars praedicandi genre. They can be found in, e.g., De modo componendi sermones cum documentis by Thomas Waleys and Ars faciendi sermones by Gerladus de Piscario. ${ }^{25}$

We can summarize the presence of Modus sermonizandi and the Quadrangulum:

\begin{tabular}{|l|l|}
\hline Modus sermonizandi & Quadrangulum \\
\hline $\begin{array}{l}\text { Brandenburg, Domstiftsarchiv und } \\
\text {-bibliothek, Ki 1952 }\end{array}$ & Admont, Benediktinerstift, Cod. 209 \\
\hline $\begin{array}{l}\text { Esztergom, Esztergomi Főszékesegyházi } \\
\text { Könyvtár, Ms. I. 213 }\end{array}$ & \\
\hline $\begin{array}{l}\text { Gdańsk, Biblioteka Gdańska Polskiej } \\
\text { Akademii Nauk, Ms. Mar. F 253 }\end{array}$ & \\
\hline $\begin{array}{l}\text { Gdańsk, Biblioteka Gdańska Polskiej } \\
\text { Akademii Nauk, Ms. 2014 }\end{array}$ & \\
\hline Melk, Benediktinerstift, Cod. 1580 & Melk, Benediktinerstift, 1580 \\
\hline & München, BSB, Clm 16508 \\
\hline $\begin{array}{l}\text { Praha, Knihovna Metropolitní kapituly, } \\
\text { D 61 }\end{array}$ & Praha, Knihovna Metropolitní kapituly, D 61 \\
\hline Olomouc, Vědecká knihovna, M I 259 & Olomouc, Vědecká knihovna, M I 259 \\
\hline & $\begin{array}{l}\text { Sankt Florian, Bibliothek des Augustiner } \\
\text { Chorherrenstifts, XI. 96 }\end{array}$ \\
\hline Vyšší Brod, Cisterciácký klášter, 92 & Vyšší Brod, Cisterciácký klášter, 92 \\
\hline Wrocław, Biblioteka Uniwersytecka, I F 311 & \\
\hline & Wrocław, Biblioteka Uniwersytecka, I Q 152 \\
\hline & Wrocław, Biblioteka Uniwersytecka, IV Q 73 \\
\hline
\end{tabular}

Table 1: Manuscripts containing the Modus sermonizandi and the Quadrangulum

22 Jacobus de Saraponte speaks about membra, which are words used for further development of the division of the sermon (which he called notabilitas). However, he also mentions that any membrum can also be used for divisions. See the following chapter that discusses his terminology.

23 Olomouc, Vědecká knihovna, M I 259, fol. 12r: Quadrangulum nichil aliud est quam membrorum posicio. Unde per quatuor tibi posui membra in quadro, ut eo expedicius invenias, quid queris.

24 Olomouc, Vědecká knihovna, M I 259, fol. 12v: Item omnia membra ad invicem posita pro uno habent inter se consonanciam, si hoc tamen sensus permittit.

25 d'Avray, Wordlists.

26 The Modus sermonizandi follows the Quadrangulum in Melk, Benediktinerstift, Cod. 1580. 
Thus, Modus sermonizandi and the Quadrangulum are both extant in only four manuscripts: Olomouc, Vědecká knihovna, M I 259, Praha, Knihovna Metropolitní kapituly, D 61; Vyšší Brod, Cisterciácký klášter, 92, where the Quadrangulum follows the Modus, and Melk, Benediktinerstift, Cod. 1580, where the Modus follows the Quadrangulum. What is peculiar is that three of these four manuscripts are from Bohemia and two of them, as will be discussed later, contain mentions of the Czech language.

Nevertheless, their close connection to Theologia est sciencia is undeniable and they should therefore be understood as integral parts of Aurissa. Aurissa thus originally consisted of three texts: the core treatise Theologia est sciencia, the additional chapter Modus sermonizandi and a list of key terms called the Quadrangulum.

\section{The Structure of Theologia est sciencia}

There were many types of sermons used in the Middle Ages. Usually, a simplified distinction is made between a homilia and a sermo modernus (or scholastic sermon). Homilies start with a longer passage from the Bible and explain it bit by bit. A sermo modernus, on the other hand, usually takes a short passage from the Bible and builds the whole sermon on this using more complex exegetical methods. ${ }^{27}$ Jacobus de Saraponte does not address the differences between these two basic types, but Aurissa concentrates completely on the structure of the sermo modernus.

According to Siegfried Wenzel, a typical scholastic sermon has the following structure (direct quotation): ${ }^{28}$

(a) The thema is announced.

(b) It is or may be followed by a protheme as a kind of prologue, which leads to

(c) A prayer for divine assistance

(d) Then the thema is repeated or resumed

(e) Some kind of connection to the next part is established, which may be what I will call a bridge passage, or else a longer

(f) Introduction of the thema.

(g) The division follows.

(h) The members of the division are confirmed. The members are then explained or further developed with various processes including

(i) Subdivisions and distinctions as well as

(j) Other processes of dilatation.

(k) At the end of the development the members may be tied together.

(l) Finally, the sermon ends with a closing formula, essentially a prayer. 
This structure is quite similar to that of the first section of Theologia est sciencia (according to Olomouc, Vědecká knihovna, M I 259): ${ }^{29}$

\begin{tabular}{|c|c|c|c|c|}
\hline \multicolumn{5}{|c|}{ Theologia est sciencia - First part, "forma" - form of the sermon } \\
\hline 1 & De theologia & & \multirow{3}{*}{\multicolumn{2}{|c|}{ General introduction }} \\
\hline 2 & De speciebus theologie & & & \\
\hline 3 & De sermone & & & \\
\hline 4 & De themate & $=$ & Thema & \multirow{13}{*}{$\begin{array}{l}12 \text { things that } \\
\text { can »occur« in } \\
\text { a sermon }\end{array}$} \\
\hline 5 & De invocacione & $=$ & Initial prayer & \\
\hline 6 & De notabilitate & $=$ & Similar to a division & \\
\hline 7 & De commixcione & & \multirow{3}{*}{$\begin{array}{l}\text { Obtaining the suitable } \\
\text { notabilitas }\end{array}$} & \\
\hline 8 & De discursu & & & \\
\hline 9 & De natura & & & \\
\hline 10 & De ampliacione & & \multirow{6}{*}{$\begin{array}{l}\text { Further development } \\
\text { of the sermon }\end{array}$} & \\
\hline 11 & De articulacione & & & \\
\hline 12 & De membracione & & & \\
\hline 13 & De probacione & & & \\
\hline 14 & De exposicione & & & \\
\hline 15 & De allusione & & & \\
\hline 16 & De conclusione & $=$ & Conclusion & \\
\hline 17 & De recapitulacione prima & $=$ & \multicolumn{2}{|l|}{ Summary } \\
\hline
\end{tabular}

Table 2: Theologia est sciencia - Contents of the first part (form)

The thema of the sermon is - of course - probably one of the most discussed elements in the treatises on the art of preaching. The fourth chapter in Theologia est sciencia is, however, very short and contains only basic advice (I paraphrase): a thema should be from the Old or New Testament, the preacher has to know from which biblical book it is and what it means, and it should be short. After saying it once, there should be an invocation (initial prayer).

Noteworthy here is the skipping of protheme, otherwise a common topic in the treatises of medieval artes praedicandi..$^{30}$ This is not by chance. In the first recapitulatio, Jacobus de Saraponte speaks against it, saying (Olomouc, Vědecká knihovna, fol. 4v):

Item non facias subthema vel prothema, sed simpliciter pone thema tuum et procede.

Never make a subtheme or protheme, but simply say your theme and continue.

29 I am using a classical orthography for terms and medieval orthography in direct quotations from manuscripts.

30 Wenzel, Medieval Artes Praedicandi, 55-59. 
Some manuscripts also mention here an uncommon term: praethema. ${ }^{31}$ However, from the context, it seems to be synonymous with prothema. It may be originally a gloss that tried to explain the Greek preposition pro by Latin prae. What is important is that the structure of the sermon should be simple and straightforward.

The invocation should, again, be short, it should mention the (biblical) source of the thema (testament, book, author, chapter), and close with a prayer, like the Pater noster or Ave Maria. After that, the thema should be recited again.

Here the treatise starts to deviate from common terminology. Usually, the thema of a sermon is divided into parts in the process called divisio (»division «). Jacobus does not use this term and instead he speaks about notabilitas which is similar to it and provides the following explanation (Wrocław, Biblioteka Uniwersytecka, I F 311, fol. 158rb):

Notabilitas est medulla ex hoc, in quo latuit sensus, exossata. Verbi gracia: "Mittamus lignum in panem eius et eradamus eum de terra vivencium. "Ecce hoc est thema, in quo tres sunt clausule, quas virgule punctant. Modo vide in eo, quod dicit "mittamus lignum", latet "iniquitatis conspiracio", sed "in panem eius" "creatoris passio", sed in hoc, quod dico »eradamus eum", etc. »erroris opinio". Ecce hec erat medulla sensus, que latuit in hiis tribus clausulis: "Mittamus lignum in panem eius" etc. Hanc medullam modo tibi exossavi, id est extraxi, quia absque dubio iudei conspirabant, Cristum crucifigebant, sed errabant.

Notabilitas is a marrow that was extracted from where the sense lies. For example: "Mittamus lignum in panem eius et eradamus eum de terra vivencium." [Jeremiah 11.19] (Let us put wood on his bread, and cut him off from the land of the living.) See this is the thema, which consists of three clauses divided by strokes [i.e. interpunction]. Now see that in "mittamus lignum " (let us put wood) there is a hidden »iniquitatis conspiracio" ("conspiracy of wickedness"), and in »in panem eius" (»on his bread«) there is "creatoris passio" ("passion of the creator"), and in "eradamus eum " ("cut him off") there is "erroris opinio" (»false opinion"). See that was the marrow of the meaning, which was hidden in these three clauses: "Mittamus lignum in panem eius" and so on. And I extracted this marrow for you, i.e. dragged it out, because without a doubt, Jews were conspiring, they were crucifying the Christ, but they were in error.

Especially important is the idea of a firm linguistical structure of these notabilitates. They should consist of two substantives, one in the genitive and one in the nominative or accusative (Wrocław, Biblioteka Uniwersytecka, I F 311, fol. 158rb):

Item nota, quod omnis notabilitas habet duos casus, scilicet genitivum, qui preponi potest vel postponi, et nominativum vel accusativum et hoc secundum formam Latinitatis.

Also note that each notability has two cases, namely genitive that can be put first or last, and nominative or accusative and that according to the Latin grammar.

Later examples provided by Jacobus de Saraponte, like »laudabilis vite status" (in De discursu), show that additional adjectives could also be a part of the notabilitas.

31 E.g.: Item numquam facias subthema vel prothema vel prethema, sed simpliciter pone thema tuum et procede. (Wroclaw, Biblioteka Uniwersytecka, I F 311, fol. 159vb). 
The author also lists alternative names for notabilitas (Wrocław, Biblioteka Uniwersytecka, I F 311, fol. 158rb-158va):

Notabilitas autem multa habet nomina, dicitur enim utilitas, meta, exemplum, consideracio, informacio, sensus.

Notability has many names, for instance it is called utility, meta, example, consideration, conception, meaning.

Why is it called notabilitas? This unusual term may come from a common opening of divisions in the style of "Hic duo/tria/etc. notantur«: I.e. "here two/three/etc. things are being noted".

Three subsequent chapters following De notabilitate deal with the question of how to find suitable notabilitates to a thema. The author proposes the following methods:

1. Commixtio (Mixing)

2. Discursus (Discourse)

3. Natura (Nature)

The commixtio combines the key terms in order to find the best one for the selected clause of the thema. There are two tools that can be used to make this specific task easier:

1) First, the aforementioned Quadrangulum (Wrocław, Biblioteka Uniwersytecka, I F 311, fol. 158va):

Illas autem notabilitates, quas commisces, a quadrangulo accipies, quia omne membrum potest fieri notabilitas et econverso et hoc in simili sensu.

You will get the notabilities to mix from the quadrangule, because each member (word) can become a notability and the other way round and that in the similar sense.

This means, the preacher may use the words from the Quadrangulum to create various combinations of suitable key terms.

2) Second, a wax tablet should serve to choose the best one among various notabilitates (Olomouc, Vědecká knihovna, M I 259, fol. 2r-2v):

Item cum sit magna vis investigare notabilitatem, fac in cerario rotham circularem et in medio rothe scribe thematis clausulam, [in] infra sperulas scribe notabilitates inductas, quibus scriptis vide, que magis notabilitas conveniat cum sensu clausule in rotha scripte, et illa est notabilitas illius clausule vel si magis placet discurre.

Also, because it is very difficult to find notabilities, create a circle in the wax tablet and write the clause from the thema in the middle, then write under the circles notabilities that you created and after you have written them down, see which one corresponds more to the meaning of that clause that is written in the circle. And that is the notability of that clause. Or if you prefer, make the discourse.

The second method is discursus (Wrocław, Biblioteka Uniwersytecka, I F 311, fol. 158va):

Discursus est transicio partis in partem sub quolibet accidenti vel contingenti.

Discourse is a transition of a part into another part under any accident or contingent. 
In other words, a preacher is supposed to determine the notabilitates through identifying shared properties of accidental qualities of terms or events connected to them (contingent). The author provides the following example (Wrocław, Biblioteka Uniwersytecka, I F 311, fol. 158va-158vb):

Verbi gracia: "Erat lucerna ardens". Ecce hic sunt due clausule. Modo discurre, quousque invenias notabilitatem, que latet in prima clausula, videlicet "Erat lucerna". Dicis ergo: O Iohannes, fuisti lucerna? Qualis lucerna? Perspicua. De quo est facta hec lucerna? De vitro vel de cornu vel quid fuit male intelligo. Corpus, sensus, fides, verbum suum, quod predicavit, erat lucerna, nam et intellectus, operacio exempli boni fuit candela in hac lucerna et ita est utique. Certe, si sic est, tunc sanctus Iohannes et status sancti Iohannis erat bonus et laudabilis. Ergo "laudabilis vite status" erat in Iohanne et ecce, hec est notabilitas "laudabilis vite status", que latuit in hac clausula »Erat lucerna". Similiter et in aliis contrariis Latine vel Teutunice vel in utroque et semper procede scalariter ascendendo secundum quod sensus est.

For example: "Erat lucerna ardens. " ("He was a burning light.«) [John5.35]. See there are two clauses. Now wander so long until you find the notability that is hidden in the first clause, namely "Erat lucerna» ("He was a light«). So you say: O, John, were you a light? And what light? The bright one. From which is that light? From glass or from horn or I don't understand well what it was. Body, senses, faith, his word that he preached - that was the light, and the intellect, performance of a good example was the candle in that light and so it is. Of course, if it is so, then St. John and the state of St. John was good and praiseworthy. Accordingly, there was a praiseworthy state of life in John and see, this is the notability "laudabilis vite status" ("praiseworthy state of life«) which was hidden in that clause »Erat lucerna«. Similarly, you can use the same approach for the contrary things [i.e. negative topics], in Latin or in German or in both and proceed always step by step and ascend according to the meaning.

Finally, there is the third method to determine suitable notabilitates, probably the most curious one, called natura. This method is usually called excoriatio and can be found in other treatises as well..$^{32}$ It is based on taking letters from one word and using them as initial letters for new words (Olomouc, Vědecká knihovna, M I 259, fol. 2v):

Natura est coagulacio athomi alicuius tocius in aliud totum, verbi gracia: "Erat lucerna ardens". In hac diccione "ardens" latet secunda notabilitas huius thematis, videlicet "Erat lucerna ardens". Modo vide, hec diccio ardens habet sex litteras, igitur accipe per quamlibet litteram diccionem integram ita, quod illa incipiatur ab illa littera, igitur per $A$ - amore, $R$ - regis, per $D$ - dei, per $E$ - eterni, per $N$ - novi, per $S$ - spirans. Modo cum diccionibus sex fac sentenciam et vide, quid resultet ex hoc, verbi gracia: Spirans, id est qui spirabat, amore regis dei eterni novi, id est incarnati. Et ex hoc erat in beato Iohanne vere caritatis declaracio.

Nature is a solidification of the minimal part of something complete into something else complete, e.g.: "Erat lucerna ardens" ("He was a burning light.") In this word "ardens" (»burning ") there is hidden the second notability of this thema, namely »Erat lucerna ardens." Now see, this word "ardens" has six letters, therefore for every letter, take a complete word that starts with that latter, so for A - "amore» (»love«), for 
$\mathrm{R}$ - »regis" (»of king«), for D - »dei« (»of God»), for E - »eterni« (»eternal«), for N "novi« ("new"), for S - "spirans" (»breathing"). Now create a sentence with these six words and see what the result from this is, e.g.: "Spirans" (»breathing «), i.e. who was breathing, "amore regis dei eterni novi, id est incarnati (»by love towards the king, eternal new God, i.e. incarnated «). And based on this, there was truly manifestation of love in St. John.

The following chapters of the first section of Theologia est sciencia focus on expansion of the sermon. Ampliatio consists of variation based on swapping prepositions for different ones and making gradations, ${ }^{33}$ articulatio is based on the preacher asking questions and then answering them.

Membratio seems rather a more universal approach. It is defined as follows (Olomouc, Vědecká knihovna, M I 259, fol. 3v):

Membracio est quedam alligacio huius, de quo quis loquitur. Poteris autem membrari in qualibet specie sermonis, id est ponere membra. Et nota, quod sicut corpus sine membris informe est, sic sermo sine membris.

"Membration" is a kind of binding to this, about what one talks. You can "membrate" any element of the sermon, i.e. add members. And note that as much as the body without members is deformed, the same [is true] for the sermon without members.

In other words, membratio ties (alligat) additional terms to any other part of the sermon. Their most common use is, however, in further development of notabilitates, where they function as a type of subdivision. Aurissa prescribes their number quite exactly (Olomouc, Vědecká knihovna, M I 259, fol. 3v):

Et nota, quod si due fuerint notabilitates, ad quamlibet pone quatuor membra.

Si autem tres, ad quamlibet duo membra.

Si autem quatuor, ad quamlibet pone unum membrum.

Et si plures notabilitates, eodem modo fac.

We can visualize it in the form of table:

\begin{tabular}{|r|l|l|}
\hline $\begin{array}{l}\text { Number of } \\
\text { notabilities }\end{array}$ & & $\begin{array}{l}\text { Number of } \\
\text { members for } \\
\text { each notability }\end{array}$ \\
\hline 2 & $\rightarrow 4$ \\
\hline 3 & $\rightarrow$ & 2 \\
\hline $4+$ & $\rightarrow$ & 1 \\
\hline
\end{tabular}

Table 3: Corresponding numbers of notabilities and members 
After membratio, the author lists probatio, which uses parts of the Bible as proof of the preacher's statements. Expositio explains the less known through the more known.

Allusio requires a little bit of explanation. It is a complicated rhetorical figure consisting of three sentences totaling 18 words that repeat in the following pattern:
A-B, A-C, A-D
B-E, C-F, D-G
B-H, C-I, D-K

The example the author provides is the following (Olomouc, Vědecká knihovna, M I 259, fol. 4r):

Adam, ubi es? Videlicet, qui

magna scivisti, magna fecisti, magna offendisti;

scivisti bonum, fecisti malum, offendisti deum;

scivisti immortalitatem, fecisti iniquitatem, offendisti trinitatem.

Adam, where are you? Namely you,

who knew great things, who did great things, who offended great things

you knew the right, you did the wrong, you offended the God;

you knew the immortality, you did inequality, you offended the Trinity.

Finally, conclusio represents simple advice regarding the final words of the sermon. The first part ends with a summary.

The second part of the treatise will be summarized only quickly here because it deals mainly with the interpretation of the scripture.

\begin{tabular}{|c|c|c|c|}
\hline \multicolumn{4}{|c|}{$\begin{array}{l}\text { Theologia est sciencia - Second part, »intelligentia« - understanding of the scripture } \\
\text { and circumstances around preaching }\end{array}$} \\
\hline 18 & De intelligencia thematis & & \multirow{9}{*}{$\begin{array}{l}\text { Interpretation of the thema } \\
\text { and other biblical passages }\end{array}$} \\
\hline 19 & De inconveniencia verborum & & \\
\hline 20 & De inconveniencia sentenciarum & & \\
\hline 21 & $\begin{array}{l}\text { De inconvenienciis quasi } \\
\text { mendaciorum }\end{array}$ & & \\
\hline 22 & De numero & & \\
\hline 23 & De opinione & & \\
\hline 24 & De equalitate & & \\
\hline 25 & De ydemptitate & & \\
\hline 26 & De exclamacione & & \\
\hline 27 & De habitu & & \multirow{5}{*}{$\begin{array}{l}\text { Practical advice concerning the style of } \\
\text { the oral delivery, remembering the ser- } \\
\text { mon, topics to avoid and finding suita- } \\
\text { ble thema for various audiences }\end{array}$} \\
\hline 28 & De actu & & \\
\hline 29 & De memoria & & \\
\hline 30 & De prohibicione & & \\
\hline 31 & De forma & & \\
\hline 32 & De quadrangulo & $=$ & $\begin{array}{l}\text { Use of the Quadrangulum device and } \\
\text { various general advice }\end{array}$ \\
\hline 33 & De recapitulacione secunda & $=$ & Second summary \\
\hline
\end{tabular}

Table 4: Theologia est sciencia - Contents of the second part (understanding of the scripture and circumstances around preaching) 
Inconveniencia verborum explains the case when terms are attributed to God or the devil that do not fit them (like deus irridebit, »God shall laugh«). Inconveniencia sentenciarum deals with contradictory sentences. Inconveniencia quasi ex mendaciis focuses on parts of the Bible that may seem not to be in accord with the truth. Similarly, Jacobus de Saraponte included chapters on the interpretation of numbers from the Bible (De numero), the difference between assertion and opinion (De opinione), using parallel passages in preaching ( $D e$ equalitate), the interpretation of passages containing the same or similar words multiple times (De ydemptitate) and the interpretation of the direct speech in Bible (De exclamacione).

Subsequent chapters focus on the delivery of sermons. In De habitu (On the habit), Jacobus describes how each sermon should have three (types of) gestures and three voices (Olomouc, Vědecká knihovna, M I 259, fol. 10v):

In quolibet sermone tuo habeas tres gestus et tres voces. Verbi gracia, quando invocas et concludis, inspicies terram semiclausis oculis et quasi tacita voce fruaris, ita tamen, ut audientes plene intelligant.

Thema autem et totum alium sermonem preter allusiones loquaris voce mediocri et facie erecta. Nullum tamen singulariter respicias, sed omnes sensus exteriores dirige ad interiorem intellectum, ut scias, quot sint notabilitates, quot membra, quot probaciones et que sunt et numquam errabis.

Cum autem alludis, erige faciem tuam et alta voce loquaris modo vertens vultum ad dexteram, modo ad sinistram, modo illum respiciens, modo istum et oculos apperi et ipsos circumfer more falconis et hoc modo in omni sermone sive Latino, sive materno procedas.

In each sermon you should have three (types of) gestures and three (types of) voices. For example, during the initial prayer and conclusion look at the ground with eyes half-closed and use a silent voice, but in such a way that listeners could still fully understand you.

Say the thema and whole rest of the sermon, except allusions, with medium voice, looking straight. However, don't look at anyone in particular but focus all your exterior senses on the interior intellect, so you know, how many notabilities there are, how many members, how many proofs and which one and then you will never err.

When you allude, raise your head and speak loudly, sometimes turn your head to the right, sometimes to the left, sometimes look at one person, sometimes at another, open your eyes and look around like a falcon and act this way in any sermon, be it in Latin or in the mother tongue. 
The chapter De actu provides probably the best understanding of the relationship between the thema, notabilitates and membra (Olomouc, Vědecká knihovna, M I 259, 10v):

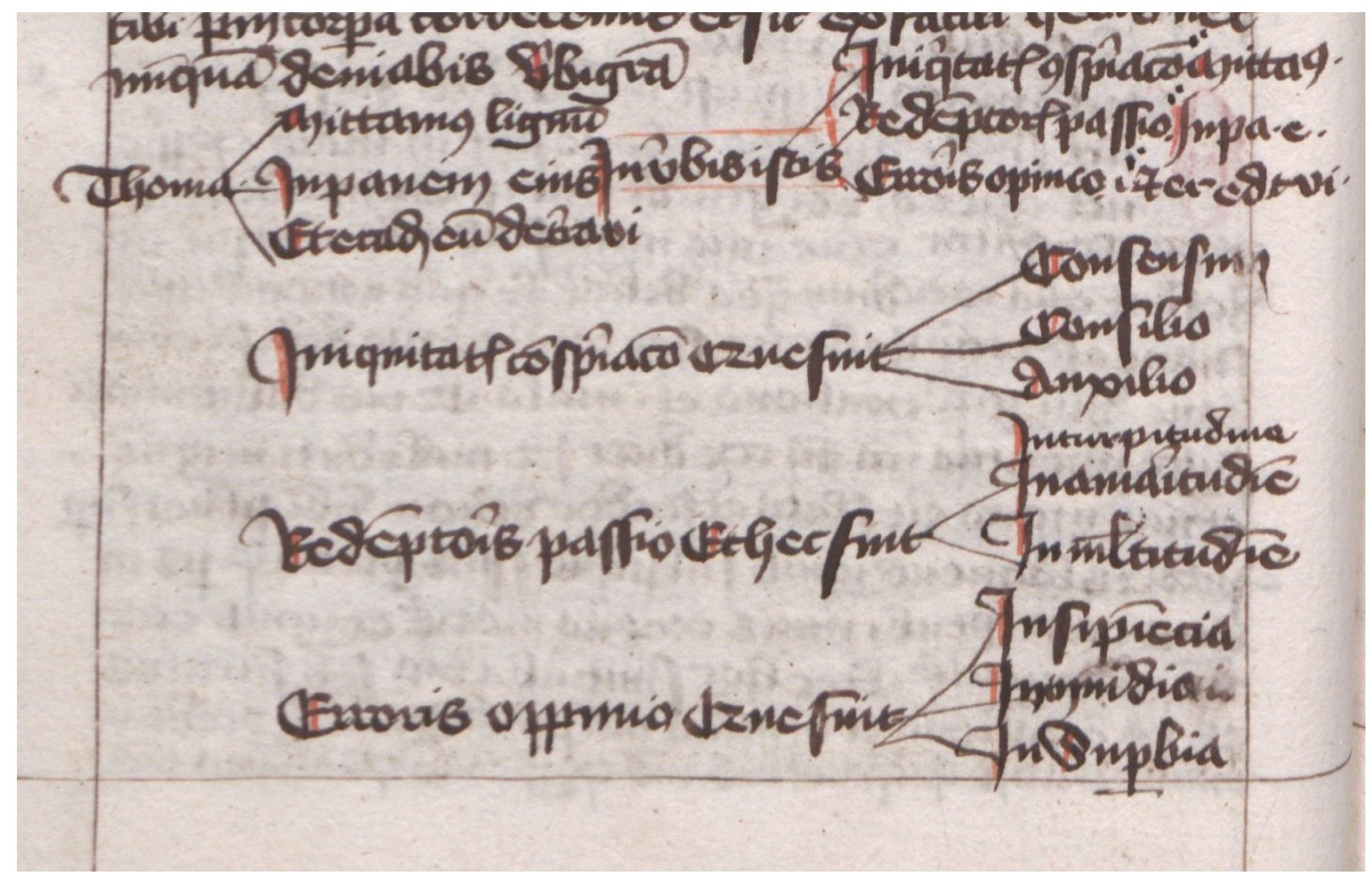

Fig. 2: Olomouc, Vědecká knihovna, M I 259, fol. $10 \mathrm{v}$

\begin{tabular}{|c|c|c|c|c|}
\hline Thema & & Notabilitates & Connection & Membra \\
\hline \multirow{3}{*}{ Mittamus lignum } & \multirow{3}{*}{$\rightarrow$} & \multirow{3}{*}{$\begin{array}{l}\text { Iniquitatis conspi- } \\
\text { racio }\end{array}$} & \multirow{3}{*}{ que fuit } & Consensu \\
\hline & & & & Consilio \\
\hline & & & & Auxilio \\
\hline \multirow{3}{*}{ In panem eius } & \multirow{3}{*}{$\rightarrow$} & \multirow{3}{*}{ Redemptoris passio } & \multirow{3}{*}{ et hec fuit } & In turpitudine \\
\hline & & & & In amaritudine \\
\hline & & & & In multitudine \\
\hline \multirow{3}{*}{$\begin{array}{l}\text { Et eradamus eum } \\
\text { de terra vivencium }\end{array}$} & \multirow{3}{*}{$\rightarrow$} & \multirow{3}{*}{ Erroris oppinio } & \multirow{3}{*}{ que fuit } & $<$ In $>$ insipiencia \\
\hline & & & & In invidia \\
\hline & & & & In superbia \\
\hline
\end{tabular}




\begin{tabular}{|c|c|c|c|c|}
\hline Thema & & Notabilities & Connection & Members \\
\hline \multirow{3}{*}{ Let us put wood } & \multirow{3}{*}{$\rightarrow$} & \multirow{3}{*}{$\begin{array}{l}\text { conspiracy of } \\
\text { wickedness }\end{array}$} & \multirow{3}{*}{ that was } & in the agreement \\
\hline & & & & in the intention \\
\hline & & & & in the aid \\
\hline \multirow{3}{*}{ on his bread } & \multirow{3}{*}{$\rightarrow$} & \multirow{3}{*}{$\begin{array}{l}\text { passion } \\
\text { of the saviour }\end{array}$} & \multirow{3}{*}{ and this was } & $\begin{array}{l}\text { in the shameful- } \\
\text { ness }\end{array}$ \\
\hline & & & & in the bitterness \\
\hline & & & & in the number \\
\hline \multirow{3}{*}{$\begin{array}{l}\text { cut him off } \\
\text { from the land of } \\
\text { the living }\end{array}$} & \multirow{3}{*}{$\rightarrow$} & \multirow{3}{*}{ false opinion } & \multirow{3}{*}{ that was } & in the foolishness \\
\hline & & & & in the envy \\
\hline & & & & in the arrogance \\
\hline
\end{tabular}

Table 5: Theologia est sciencia - Second part, »intelligentia" - Diagram of thema, notabilitates and membra

The chapter on memory offers simple advice: the need to remember the most crucial terms of the sermon, especially the notabilites and membra. If something goes wrong and a preacher forgets them, then he can use a quotation from an authority or an exclamation. In the chapter De prohibicione Jacobus de Saraponte also advises the preachers against speaking about certain, theologically complex topics like the Trinity. The subsequent chapter, De forma, admonishes the preacher to adapt his topic to his audience (chapter, nobles, soldiers, nuns, city or countryside). The chapter De quandrangulo analyzed above follows, and the section again closes with a recapitulatio.

\section{Multilingual Preaching}

In several significant passages the treatise refers to multilingual preaching. They can be found in these chapters: ${ }^{34}$

1. De discursu

2. De recapitulacione prima

3. De quadrangulo

And in the addition

4. Modus sermonizandi

34 Latin and the mother tongue are also mentioned in the chapter De equalitate and De habitu simply stating that the chapter is valid for both languages. 
Recapitulatio follows the structure of the treatise. The first mention of multiple languages concerns the topic of rhyme (Esztergom, Esztergomi Főszékesegyházi Könyvtár, Ms. I. 213, fol. 19r):

Item si sermo fuerit Latinus totaliter, consonanciam in notabilitatibus et in allusionibus servabis. Si autem totus sermo fuerit in Teutunico, predictam consonanciam non servabis, nisi velis et lingwa matris tue consenciet. ${ }^{35}$

Also, if the sermon is completely in Latin, you should preserve the consonance [i.e. rhyme] in notabilities and in allusions. However, if the sermon is in German, you don't have to preserve the said consonance, unless you want and your mother tongue allows that.

In other words, the rhyme is only expected to be preserved in the Latin preaching, not in the vernacular. The following rule explains the language of the thema in a vernacular sermon (Esztergom, Esztergomi Főszékesegyházi Könyvtár, Ms. I. 213, fol. 19r):

Item in Teutunico sermone penitus nullum dicas Latinum, sed bis tantum thema in Latino, videlicet in principio sermonis et facta invocacione iterum thema repete in Latino. Et hoc intellige, si audientes puri fuerint layci.

Also, in a sermon that is completely in German, don't say anything in Latin except twice the thema in Latin, namely at the beginning of the sermon; and after making the invocation repeat the thema in Latin. And follow this, if the listeners are pure laymen.

Then the mixing of languages is addressed (Budapest, Esztergom, Esztergomi Föszékesegyházi Könyvtár, Ms. I. 213, fol. 19r):

Item si sermo tuus fuerit intermixtus vel si monialibus sermonizas, tunc sit in arbitrio tuo, quando loquaris Latinum vel quando maternum.

Also, if your sermon will be mixed or if you preach to nuns, then it is up to your judgement when you speak in Latin and when in the mother tongue.

It seems the sermon for nuns presented some difficulties for the copyists. We can also find alternative readings, like moralibus instead of monialibus (Graz, Universitätsbibliothek, Ms. 971, fol. 3vb), an addition of in materno after monialibus sermonizas (St. Florian, XI. 96, fol. 159va), or monialibus sermonizas in Theutunico vel materno (Brandenburg, Ki 1952, fol. 5v) etc. These changes and additions may be the result of confusion on the part of the scribe, who tried to clarify the matter.

In this respect, it is interesting also to look at the same passage in the excerpts from Aurissa extant in München, BSB, Clm 4784, fol. 151v:

Si vero sermo tuus fuerit intermixtus, [tunc] tunc ad placidum tuum modo tamen congruo et tempore oportuno sermoni vulgari vel materno admiscere potes Latinum.

If, in fact, your sermon will be mixed, then you can add Latin to your sermon in the vernacular or in the mother tongue as you wish, however, in the right way and at a suitable time.

Wrocław, Biblioteka Uniwersytecka, I Q 152, fol. 284r has a peculiar reading here: instead of et lingwa matris tue consenciet it has et ligwis (sic!) matris tue consenciat. The use of plural (ligwis) may, however, be a scribal error. 
In Aurissa, Jacobus postulates that the invocation should be in Latin only in sermons that are pronounced entirely in Latin, otherwise, it should be presented in the vernacular (Esztergom, Esztergomi Főszékesegyházi Könyvtár, Ms. I. 213, fol. 19r):

Item nota, quod numquam invocabis in Latino, nisi sermo tuus fuerit totus Latinus. Et invoca breviter, nec queras ambagies.

Also, note that you should never invoke in Latin, unless your sermon is full in Latin. And invoke shortly and don't look for digressions.

In the summary on the further make-up of the sermon, recapitulatio discusses the use of various languages only in a few instances. First, regarding the second way to find proper notabilitates, the so-called discursus (Esztergom, Esztergomi Főszékesegyházi Könyvtár, Ms. I. 213, fol. 19r):

Item circa discursum procede in Latino vel in materno vel in utroque et hoc secundum placitum tuum.

Also, regarding the discourse, proceed in Latin, the mother tongue or both and do that as you wish.

This is practically the same advice that also appears in the chapter De discursu (Esztergom, Esztergomi Főszékesegyházi Könyvtár, Ms. I. 213, fol. 18r):

Similiter et in aliis contrariis Latine vel Theutunice vel in utroque et semper procede scalariter ascendendo secundum quod sensus est.

Similarly, you can do it in the contrary things [i.e. negative topics], in Latin or in German or in both and proceed always step by step and ascend according to the meaning.

This part is especially noteworthy because it points to the possibility of active mixing of languages (in utroque). From the context, this would mean that preachers could switch between languages in their process of finding suitable notabilitates.

Regarding the allusion, recapitulatio only mentions that at least one should be present in all types of sermons, incl. the mixed one (Esztergom, Esztergomi Főszékesegyházi Könyvtár, Ms. I. 213, fol. 19v):

Item omnis allusio fiat sicut docui et adminus semel in quolibet sermone alludas, qualis eciam fuerit sermo, sive Latinus, sive maternus, sive intermixtus.

Also, each allusion should happen as I taught you and you should allude at least once in every sermon, not regarding whether it is Latin, in the mother tongue or mixed.

Finally, the conclusion should be in Latin in the Latin sermon, multilingual sermon or in a sermon for nuns. It should be in the vernacular only in a purely vernacular sermon (Esztergom, Esztergomi Főszékesegyházi Könyvtár, Ms. I. 213, fol. 19v):

Item omnis conclusio tua fiat subtiliter et brevibus verbis. Et si fuerit sermo Latinus vel intermixtus vel monialibus, conclusio tota fiat in Latino. Si autem fuerit Theutunicus sermo totaliter, conclusio tota fiat in materno. 
Also, every conclusion should be done finely and shortly. And if your sermon will be in Latin or mixed, or for nuns, the whole conclusion should be done in Latin. However, if your sermon will be in German completely, then the whole conclusion should be done in the mother tongue.

In the chapter De quadrangulo, besides special advice regarding preaching in the chapter that will be commented on later, we also find the following note on the translation of different membra (Esztergom, Esztergomi Főszékesegyházi Könyvtár, Ms. I. 213, fol. 24r):

Item si aliquod membrum positum in Latino non poteris in materno exprimere, tunc illud exprimas per similitudinem vel per circumlocucionem. Econverso autem, si membrum in materno positum non vales exprimere in Latino, fac similiter.

Also, if you cannot express a Latin word in the mother tongue, then explain it in similar words or through description. And on the other hand, if you are not able to express a vernacular word in Latin, do the similar thing.

The context of this part is using the Quadrangulum, i.e. the list of rhymed words that could be used for finding appropriate notabilitates, membra and allusiones. The formulation of the advice seems to suggest that the Quadrangulum should also contain a list of German words - which is unfortunately not the case in any manuscript I analyzed. Nevertheless, it seems to suggest that the user should translate Latin words into the vernacular and vice versa.

\section{Preaching in the Chapter}

The peculiar aspect of Aurissa is that it also provides special language advice on preaching in the chapter (in capitulo). This appears in two places: firstly, as the part of Theologia est sciencia at the end of the chapter De quadrangulo and then in some manuscripts in the following Modus sermonizandi. Because of their importance, the relevant passages are transcribed here. The first passage reads (Wrocław, Biblioteka Uniwersytecka, I F 311, fol. 163vb):

Item meum est consilium, quocienscumque in capitulo feceris sermonem, facta invocacione in ligwa matris statim in Latino repete et distinctis notabilitatibus primam notabilitatem totam dicas in Latino, qua dicta tunc primum incipe maternum et prenumera omnes notabilitates a themate ductas. Et premissa prima notabilitate, quam posuisti in Latino, prosequaris alias notabilitates cum suis membris in materno. Potes tamen auctoritates, probaciones, exclamaciones infra sermonem premittere in Latino, tamen statim debes eos (sic!) iterum repetere in materno.

Item, quando alludis, hoc fac ante conclusionem et semper primo fiat in Latino, ita si fueris in capitulo. Deinde alludas in materno, tamen tunc non attendas consconanciam aliquam, nisi velis et tuum ydioma hoc expedite admittat.

Also, my advice is that every time you preach in the chapter, invoke in the mother tongue, then immediately repeat [thema] in Latin and after proposing notabilities, explain the whole first notability in Latin, [and] after that, start in the mother tongue and enumerate all notabilities extracted from the thema. And skipping the first notability that you exposed in Latin, follow all other notabilities with their parts (membra) in the mother tongue. You can quote authorities, add proofs, exclamations within the sermon in Latin, however, you have to immediately repeat them in the vernacular. 
Also, when you allude, do that before the conclusion and it has to be always done in Latin, if you are in chapter. Then make the allusion in the mother tongue, however, then don't care about any consonance, unless you want to and your language allows to do it well.

This part is then expanded on in the addition Modus sermonizandi (Esztergom, Esztergomi Főszékesegyházi Könyvtár, Ms. I. 213, fol. 25r):

\section{Modus sermonizandi in capitulo}

Primo dic thema in Latino, deinde thema dic in Theutunico, quo dicto statim invoca in Theutunico. Et illo dicto, quod invocacione postulaveras, statim thema repetas in Latino.

Distingue clausulas in Latino et pone notabilitates in Latino. Et primam notabilitatem cum suis membris totam prosequere in Latino, qua prosec $<u>$ ta iterum thema repete in Latino. Quo repetito tunc primo incipe Theutunicum.

Distingue clausulas in Theutunico, pone omnes notabilitates in Theutunico. Et premissa prima notabilitate cum suis membris, quam exposuisti in Latino, prosequere alias notabilitates cum suis membris in Theutunico. Et breviter loquendo postquam primam notabilitatem cum suis membris exposuisti in Latino, postea per totum sermonem procedas in Theutunico, nisi aliquando permittas aliquam auctoritatem vel exclamacionem vel allusionem vel exposicionem in Latino. Et tunc statim eandem repete in Theutunico.

Method of preaching in the chapter

First say the thema in Latin, then say it in German, after that immediately invoke in German. After saying, what you asked for in the invocation, repeat immediately the thema in Latin.

Separate the clauses in Latin and propose notabilities in Latin. And follow the first notability with all its parts in Latin, after doing that, repeat again the thema in Latin. After repeating it, then firstly start with German.

Separate the clauses in German and propose all notabilities in German. And skipping the first notability, that you explained in Latin, follow other notabilities with their parts in German. And after you explained the first notability with its parts in Latin, speak shortly and proceed in the whole sermon in German, unless you sometimes allow some authority, exclamation, allusion or exposition in Latin. And then repeat it immediately in German.

Both passages provide practically the same advice. In the chapter, the preacher should start with the thema in Latin, translate it into German and then make the invocation. As the first excerpt suggests, the invocation should be in German. Then the thema should be repeated again in Latin. No German translation is mentioned here. This is followed by the most complicated and peculiar part: bilingual notabilitates.

The first one should be said in Latin with all its parts. It is not completely obvious whether this means that the whole division should be said in Latin or just the notabilitas with its members without further exposition. The thema should then be repeated in Latin again. At this point, the preacher should switch into German. 
The preacher enumerates again all notabilitates in German. The following part is not completely clear, but it seems that the preacher should then skip the first notability that he already explained in Latin, and continue directly with the others in German. He may still use Latin though, in authorities, exclamations, allusions and expositions. All of these should be immediately translated into German. As we learned before, the conclusion in the case of mixed sermons should be in Latin.

It appears that the author meant primarily a chapter room of a monastery, where sermons took place, since he uses the phrase in capitulo ordinis once in connection with choosing the right topic for the preaching - in this case something related to a feast. ${ }^{36}$ This would also explain another passage where he describes how if the preacher stands in the middle of laymen, he should turn around so everybody can perceive his sermons equally. ${ }^{37}$ This could describe a situation known, e.g., from Cistercian monasteries, where sermons in a chapter room on feast days were also attended by lay brothers who did not necessarily know Latin. Sermons of a Czech Cistercian of German origin, Peter of Zittau (†1339), from the famous monastery of Aula Regia in Zbraslav, near Prague, show that already in the 14th century, at least some Cistercians used the vernacular language in the oral delivery for the body of the sermon when lay brothers were present. ${ }^{38}$

\section{German Readers and Bohemian Adaptations}

Unfortunately, there are very sparse marginal notes in the manuscripts that would tell us more about how this work was actually used. However, there is an interesting short note in Gdańsk, Biblioteka Gdańska Polskiej Akademii Nauk, Ms. Mar. F 253, fol. 164r. ${ }^{39}$ Here a reader added just one word on the margin to the chapter De habitu: beyspelen, i.e. a German word for »example«:

36 Wrocław, Biblioteka Uniwersytecka, I F 311, 163rb: Talem habebis formam si in capitulo ordinis dogatizas, thema tuum sit de festo vel tale, quod possit appropriari presenti festivitati.

37 Wrocław, Biblioteka Uniwersytecka, I F 311, 163ra: Item nota, si laicis sermonisas et ipsi ex omni parte circumstant te vel sedent et tunc tu in medio eorum stas, tunc quandoque vertas te naturaliter sicut tarda rota, ut omnes equaliter percipiant dogma tuum.

38 Peter of Zittau, Sermons on the Principal Feasts, ed. Pumprová, 48-50.

39 A marginal gloss was also copied with the text into Gdańsk, Biblioteka Gdańska Polskiej Akademii Nauk, Ms 2014, fol. 209r. 


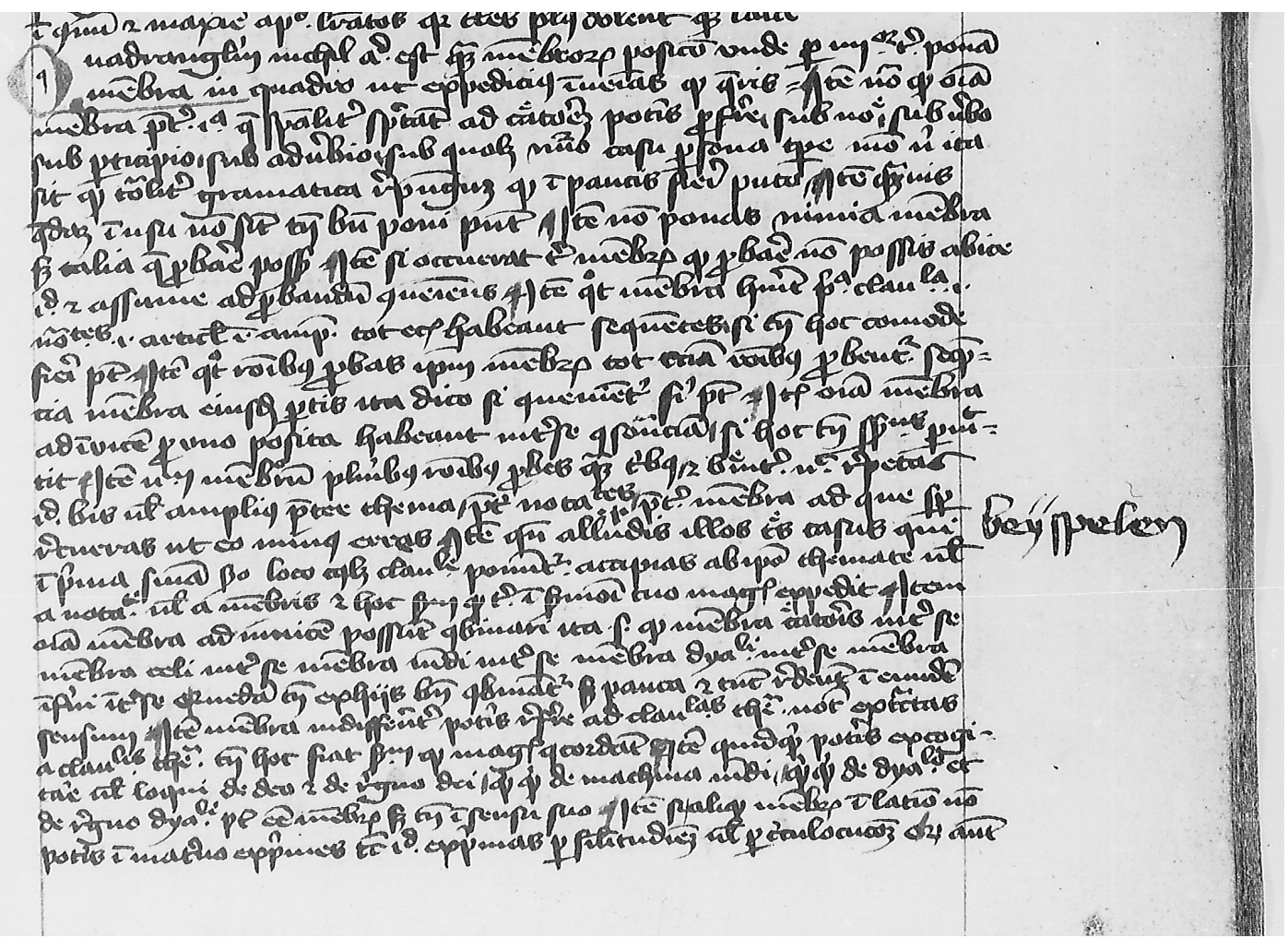

Fig. 3: Gdańsk, Biblioteka Gdańska Polskiej Akademii Nauk, Ms. Mar. F 253, fol. $164 r$

This is interesting, especially from the perspective that Aurissa otherwise does not contain any German or vernacular words at all.

Aurissa was also locally adapted, as three manuscripts of Bohemian origin show. The manuscript currently kept in the Cistercian monastery in Wilhering (Zisterzienserkloster, Cod. IX 122) substitutes all occurrences (except one) of the term Theutunicum (»German«) with maternum ("mother tongue») or even Boemicum ("Czech language»). ${ }^{40}$

There are, however, two even more curious cases. The first one is Olomouc, Vědecká knihovna, M I 259 that otherwise provides a very good text and is one of the few manuscripts containing all the original parts of the treatise (i.e. Theologia est sciencia, Modus sermonizandi and the Quadrangulum). The Olomouc manuscript substitutes all occurrences of Theutunicum with Boemicum. However, probably a subsequent reader was not happy with this change. First, in the chapter on discursus, he crossed out the first occurrence of Boemice and wrote on the margin $<$ in $>$ vulgari ligwa (»<in> the vernacular language $«):{ }^{41}$

40 E.g. Item meum consilium est, quocienscumque in capitulo feceris sermonem, facta invocacione in lingua materna, statim thema repete Latine repente et distinctis notabilitatibus primam notabilitatem totam dicas, qua dicta tunc primo incipe Boemice et prenumera omnes notabilitates ad Boemicum ductas et pretermissa prima notabilitate, quam posuisti in Latino, prosequaris alias notabilitates cum suis membris in materno. (fol. 117r)

41 Olomouc, Vědecká knihovna, M I 259, fol. 2 v. 


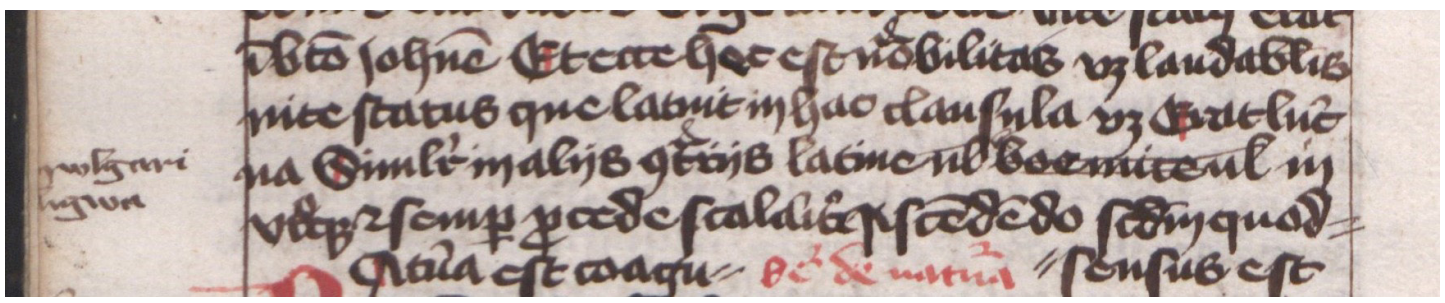

Fig. 4: Olomouc, Vědecká knihovna, M I 259, fol. $2 v$

However, in later occurrences, he usually simply used interlinear glosses to write above every other occurrence of Boemicum (»Czech») the Theutunicum (»German«). This can be observed well in the first recapitulatio (Olomouc, Vědecká knihovna, M I 259, fol. 4v):42

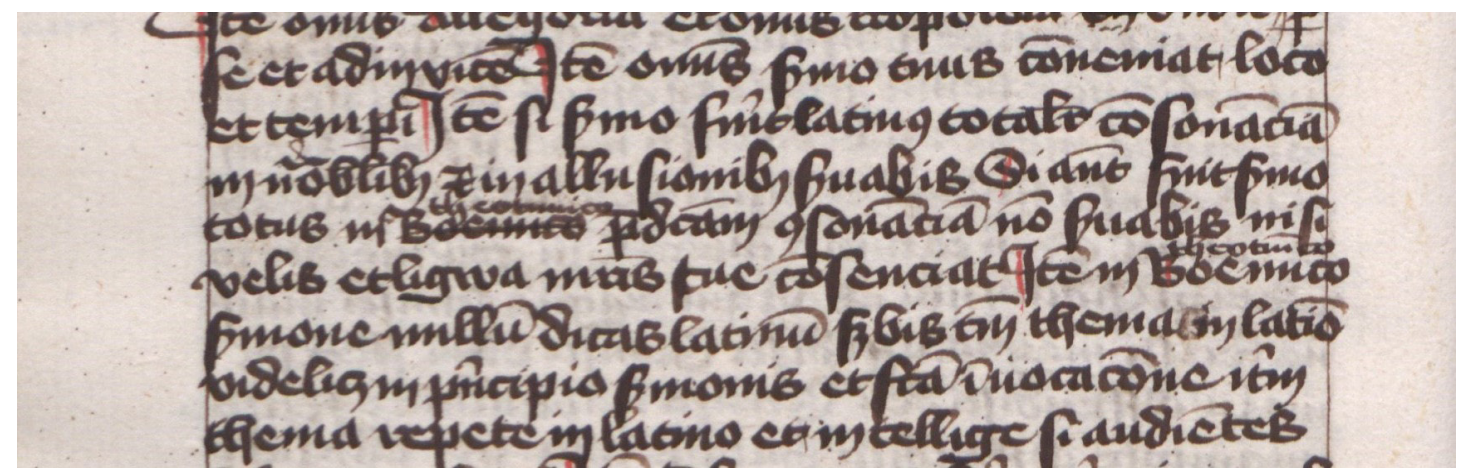

Fig. 5: Olomouc, Védecká knihovna, M I 259, fol. 4 v

This seems to be a testimony to a multiple reception of the text: first it was probably accommodated by Czech users by replacing German with Boemicum, then re-accommodated by German readers again. It is also notable that the manuscripts from Wilhering and from Olomouc do not completely overlap in their use of Boemicum - this may suggest two independent Czech adaptations of Aurissa.

The second curious case is in the manuscript from Vyšší Brod, Cisterciácký klášter, 92. In this manuscript, we can find not only Latin, German and Czech as languages of preaching but even their different combinations. If we took them at face value, they would contradict themselves, e.g., in its version of Modus sermonizandi, we read (fol. 190v):

Primo dic thema in Latino, deinde dic thema in vulgari vel Theutunice, quo dicto statim invoca in vulgari vel Bohemice et illo dicto, quod invocacione postulaveras, statim thema repete in Latino.

First say the thema in Latin, then say it in the vernacular or in German, after that immediately invoke in the vernacular or Czech. After saying what you asked for in the invocation, repeat immediately the thema in Latin. 
Then in other sentences of the same part, there is no mention of German at all (fol. 190v):

Distingue clausulas in Bohemico, pone omnes notabilitates in Bohemico.

Separate the clauses in Czech and propose all notabilities in Czech.

Could it be possible that there is a connection between the manuscripts from Olomouc and from Vyšší Brod? Could either the Olomouc scribe move mentions of Theutunicum into the interlinear space or the scribe of Vyšší Brod integrate interlinear glosses from Olomouc into the text (partially and imperfectly)? It is difficult now to completely exclude these possibilities; however, both seem improbable. The nature of Vyšši Brod seems to be simply too inconsistent in this regard. Also, the first instance of Bohemicum in the Olomouc manuscript is very clearly crossed out with a marginal gloss (see Fig. 4) that does not have an expected equivalent in Vyšší Brod. Among other reasons, there is also the Quadrangulum. The version in Vyšší Brod is longer and has a different structure than the one in Olomouc. The Olomouc version could not, therefore, be a model for Vyšší Brod and the other direction seems unlikely.

Also intriguing is a possible relationship between the manuscript from Vyšší Brod and that from Wilhering. The latter in fact, originally belonged to the monastery of Vyšší Brod, a Cistercian monastery in south west Bohemia that was originally occupied by monks from Wilhering. However, later the monastery also started to accept Czech monks and it became bilingual. ${ }^{43}$ This bilingual situation may have contributed to the creation of these manuscripts and the manuscript Vyšší Brod, Cisterciácký klášter, 92 could influence the creation of the Wilhering, Zisterzienserkloster, Cod. IX 122. In this case, the inconsistent nature of the manuscript from Vyšší Brod may perhaps be a witness of gradual, not yet completed adaptation. The detailed relationship between all three manuscripts still has to be established.

This gives rise to an important question: why where these language changes necessary at all? Couldn't Czech users simply replace Theutunicum with Bohemicum mentally? And when already written, why did the German user (if the presented theory is right) change it back to Theutunicum again with so much consistency? This is especially striking if we consider that the treatise does not contain any language-specific advice that would not work in German as well as in Czech or any other vernacular. However, this may be related to the need to appropriate the text by the reader, the desire to make it their own by adapting it to their own discourse and their specific situation.

43 Bok, Literaturpflege, 182. 


\section{Conclusion}

In the sixth chapter of his monograph Macaronic Sermons, Siegfried Wenzel collected evidence supporting the concept of multilingual preaching. He quoted examples from sermons from England where which language the preacher should address the audience in is mentioned, like in this example of translation of thema: ${ }^{44}$

Extrema gaudii luctus occupat, Prouerbiorum 14. Karissimi, ista verba, que nunc dixi in latinis possunt sic dici in Anglico:

Worliche blysse and joye al-so

Enditez in sorwe and wo.

Mourning taketh hold of the end of joy, ${ }^{45}$ Proverbs 14 . Dear ones, these words, that I said now in Latin, can be said in this way in English:

Worliche blysse and joye al-so

Enditez in sorwe and wo.

Similarly, he mentions an example in the sermons of Ranulphe de la Houblonnière (c. 1225?1288). One passage of his sermon preached to a mixed audience of laymen and clergy was said in Latin in order to prevent common folks from understanding it. ${ }^{46}$ Finally, Siegfried Wenzel quotes handbooks on preaching, texts from the genre of Artes praedicandi, among them the incipit of Modus sermonizandi according to catalogues where it is recommended to pronounce the thema first in Latin and then in the vernacular. ${ }^{47}$

The treatise by Jacobus de Saraponte, Aurissa, provides crucial material for this very important question. It describes not only Latin and vernacular sermons, but Latin, mixed and vernacular ones - and many types on the continuum in between, starting from Latin sermons for clerics, to Latin sermons with the invocation in the vernacular, to mixed sermons of various types for the chapter and nuns, to vernacular sermons with just a sprinkle of Latin in the form of the thema and a Latin conclusion, and, finally, to completely vernacular sermons. Different parts of a sermon could be pronounced in different languages and, in the case of the chapter, different notabilities could even be explained and developed both in Latin and the vernacular.

However, in all these cases, the use of particular languages follows some type of instruction or even order. Could there also be mixing of languages within sentences? Or even (for the lack of a better term) macaronic preaching, as Siegfried Wenzel concluded in his monograph?

There are only three parts in Aurissa suggesting this possibility:

1) The instruction regarding the discursus says that the preacher can proceed in Latin, in the vernacular or in both.

2) The chapter about the Quadrangulum says that the preacher can explain Latin words in the vernacular with similar words or through description - and the same for vernacular words being translated into Latin. This could be understood in the context of translating the

\footnotetext{
44 Wenzel, Macaronic sermons, 108.

45 Biblical translations into English here and elsewhere are taken from the Douay-Rheims' Bible, accessed on 25 May 2021: www.drbo.org.

46 Wenzel, Macaronic sermons, 121.

47 Wenzel, Macaronic sermons, 108.
} 
thema, notabilitates, auctoritates, probationes, exclamationes, allusiones from one language into another, as described, e.g., in the part about preaching for the Chapter.

3) Finally, there is the key passage about the mixed sermon or a sermon for nuns where sit in arbitrio tuo, quando loquaris Latinum vel quando maternum, i.e. a preacher can decide for himself when to speak in Latin or in the vernacular. However, even this could be understood as applying for whole parts or sentences, not for single words. The most convincing is, therefore, the part about discourse that does not seem to allow any other interpretation than code-switching at least between sentences, if not within them. Unfortunately, Jacobus de Saraponte does not provide any example here and thus this interpretation can be only taken cautiously.

Aurissa was undeniably popular; it was read, copied and adapted by many users. But did preachers actually follow its advice regarding the use of multiple languages? Latin themata in vernacular sermons are a well-known phenomenon, but other elements mentioned in Aurissa seem to be less standard. This is especially true for the passage on the preaching in the chapter with its complicated instruction concerning the structure of the sermon and switching between the language in the first notability and the following ones.

Here, in this question, we meet the crucial problem - we have to rely on written sermons to judge the multilingualism of their delivery. It has to be taken into consideration that we are dealing simultaneously with two interconnected, yet still separate multilingual situations - multilingual written sermons and multilingual preaching. Multilingual written sermons could be delivered perfectly monolingually (either in Latin or in a vernacular) while multilingual preaching could be based on monolingual written sermons - or even on multilingual ones but transformed into a different form of multilingualism. But it is exactly this issue that makes other witnesses of multilingual preaching, like Aurissa, so valuable despite their unique flaws. 


\section{References}

\section{Abbreviations}

$\mathrm{BSB}=$ Bayerische Staatsbibliothek

BG PAN = Biblioteka Gdańska Polskiej Akademii Nauk

\section{Manuscripts}

Admont, Benediktinerstift, Cod. 209.

Basel, Universitätsbibliothek, A II 36.

Bernkastel-Kues, Bibliothek des St. Nikolaus-Hospitals, 104.

Brandenburg, Domstiftsarchiv und -bibliothek, Ki 1952.

Darmstadt, Universitäts- und Landesbilbiothek Darmstadt, Hs. 668.

Esztergom, Esztergomi Főszékesegyházi Könyvtár, Ms. I. 213.

Gdańsk, BG PAN, Ms. Mar. F 253.

Gdańsk, BG PAN, Ms. Mar. F 295.

Gdańsk, BG PAN, Ms. 2014.

Göttweig, Benediktinerstift, Cod. 250 (red).

Graz, Universitätsbibliothek, Ms. 348.

Graz, Universitätsbibliothek, Ms. 928.

Graz, Universitätsbibliothek, Ms. 971.

Leipzig, Universitätsbibliothek Leipzig, Ms 158.

Melk, Benediktinerstift, Cod. 1580.

München, BSB, Cgm 660.

München, BSB, Clm 4784.

München, BSB, Clm 12389.

München, BSB, Clm 16226.

München, BSB, Clm 16508.

Olomouc, Vědecká knihovna, M I 259.

Praha, Knihovna Metropolitní kapituly, D 61.

Praha, Knihovna Metropolitní kapituly, F 75.

Praha, Národní knihovna, VIII A 19.

Sankt Florian, Bibliothek des Augustiner Chorherrenstifts, XI. 96.

Tübingen, Universitätsbibliothek, Mc 127.

Vyšší Brod, Cisterciácký klášter, 92.

Warszawa, Bibliotheka Narodowa, Lat.Q.ch.I.57 (lost).

Wien, Österreichische Nationalbibliothek, Cod. 4553.

Wien, Schottenstift, 232.

Wilhering, Zisterzienserkloster, Cod. IX 122.

Wrocław, Biblioteka Uniwersytecka, I F 311.

Wrocław, Biblioteka Uniwersytecka, I Q 152.

Wrocław, Biblioteka Uniwersytecka, IV Q 73. 


\section{Literature}

Caplan, Harry, Mediaeval Artes Praedicandi: A Supplementary Hand-List (Ithaca, 1936).

Charland, Thomas M., Artes praedicandi: Contribution à l'histoire de la rhétorique au Moyen Âge (Paris, 1936).

Bataillon, Louis-Jacques, Approaches to the study of medieval sermons, Leeds Studies in English 11 (1980) 19-35.

Bok, Václav, Literaturpflege im Kloster Vyšší Brod/Hohenfurt vom 13. bis zum 15. Jahrhundert, in: Anton Schwob and Karin Kranich-Hofbauer (eds.), Zisterziensisches Schreiben im Mittelalter: Das Skriptorium der Reiner Mönche: Beiträge der Internationalen Tagung im Zisterzienserstift Rein, Mai 2003, Jahrbuch für Internationale Germanistik, Reihe A: Kongressberichte 71 (Bern, 2005) 179-191.

d'Avray, David L., The Wordlists in the "Ars Faciendi Sermones" of Geraldus de Piscario. Franciscan Studies 38 (1978) 184-193.

Kaliszuk, Jerzy, Codices deperditi: średniowieczne rękopisy łacińskie Biblioteki Narodowej utracone w czasie II wojny światowej [Codices deperditi: medieval Latin manuscripts of the National Library lost during World War II], 2/2 (Wrocław, 2016).

Morenzoni, Franco, Les prédicateurs et leurs langues à la fin du Moyen Âge, in: Peter von Moos (ed.), Zwischen Babel und Pfingsten: Sprachdifferenzen und Gesprächsverständigung in der Vormoderne (8.-16. Jh.) (Vienna, 2008) 501-518.

Patera, Adolf, Mistra Jana Husi česká kázání na posvěcenie kostela a na sv. Trojici [Master Jan Hus's Czech sermons for the consecration of the church and for the Holy Trinity], Vèstník Královské české společnosti nauk, Tř́da filosoficko - historicko - filologická 15 (1891) 355-385.

Pavel, Rafael, Beschreibung der im Stifte Hohenfurt befindlichen Handschriften, in: Die Handschriften-Verzeichnisse der Cistercienser-Stifte 2.2 (1891) 165-461.

Peter of Zittau, Sermons on the Principal Feasts, ed. Anna Pumprová (Dolní Březany, 2020).

Tříška, Josef, Příspěvky k středověké literární universitě: III. Pragenses magistri, praedicatores, notarii [Contributions to the Medieval Literary University: III. Pragenses magistri, praedicatores, notarii], Acta Universitatis Carolinae: Historia Universitatis Carolinae Pragensis: Př́spěvky k dějinám Univerzity Karlovy 10/1 (1969) 7-48.

Vilikovský, Jan, Kazatelství a počátky české prózy [Preaching and the beginnings of Czech prose], Řád 6 (1940) 285-296.

Wenzel, Siegfried, Macaronic Sermons: Bilingualism and Preaching in Late-Medieval England (Ann Arbor, 1994).

Wenzel, Siegfried, Art of Preaching: Five Medieval Texts and Translations (Washington, D.C., 2013)

Wenzel, Siegfried, Medieval Artes Praedicandi: A Synthesis of Scholastic Sermon Structure (Toronto, 2015)

\section{List of figures}

Fig. 1: Olomouc, Vědecká knihovna, M I 259, fol. 15r

Fig. 2: Olomouc, Vědecká knihovna, M I 259, fol. 10v

Fig. 3: Gdańsk, Biblioteka Gdańska Polskiej Akademii Nauk, Ms. Mar. F 253, fol. 164r

Fig. 4: Olomouc, Vědecká knihovna, M I 259, fol. 2v

Fig. 5: Olomouc, Vědecká knihovna, M I 259, fol. 4v 


\section{List of tables}

Table 1: Manuscripts containing Modus sermonizandi and the Quadrangulum

Table 2: Theologia est sciencia - Contents of the first part (form)

Table 3: Corresponding numbers of notabilities and members

Table 4: Theologia est sciencia - Contents of the second part (understanding of the scripture and circumstances around preaching)

Table 5: Theologia est sciencia - Second part, »intelligentia« - Diagram of thema, notabilitates and membra 